\title{
\begin{tabular}{lllllllllllllllll}
$W$ & $I$ & $A$ & $D$ & $O$ & $M$ & $O$ & S & $C$ & $I$ & $I$ & $U$ & $W$ & $A$ & $G$ & $I$ \\
\hline
\end{tabular}
}

\section{WYKOPALISKA W NAZARET}

W roku 1955 w czasie od marca do lipca na miejscu zniszczonej Bazyliki Zwiastowania przeprowadzono prace wykopaliskowe. Poszukiwania prowadzili OO. Franciszkanie, kierował nimi B. Bagatti.

Badania obejmowały miejsce, na którym znajdowała się $\mathrm{Ba}$ zylika jak i teren najbliżej położony.

Biorąc za punkt wyjścia fundamenty kościoła bizantyjskiego, badania posuwały się $w$ trzech kierunkach, mianowicie: północnym, zachodnim i wschodnim.

Budowle, jakie znajdują się od strony południowej kościoła uniemożliwiają poszukiwania archeologiczne.

Odkopana powierzchnia była prawdopodobnie najbardziej wysuniętą w kierunku południowym częścią starodawnego osiedla. Dla założenia tego osiedla wykorzystano skaliste wzgórze.

Wykopaliska trwające kilka miesięcy dały następujące wyniki: na miejscu zniszczonej bazyliki, idąc ciągle w głąb poprzez znane już dawniej fundamenty kościoła Krzyżowców, zburzonego doszczętnie w roku 1263, natrafiono na ślady innej jeszcze budowli. Są to fundamenty niewielkiego kościoła bizantyjskiego. Kościół ten według zdania Bagatti'ego powstał w 427 roku. Na całość niedużego kościoła składały'się: absyda, zakrystia, nawa, przedsionek i wejście do Groty Zwiastowania.

Jak wskazują dalsze ślady, kościół z roku 427 powstał już na ruinach jakiejś budowli przeảbizantyjskiej. Struktury tej budowli nie dało się jednak cdiworzyć. Jest prawdopodobne, że wspomniana budowla przedbizantyjska służyła również dla celów kultu religijnego. W obrębie resztek fundamentów Bazyliki znajduje się Grota Zwiastowania, zwana Swiętą Grotą, dotąd jeszcze gruntowrie nie zbadana. Zreszta nie zachowała ona pierwotnej swej formy, ponieważ, przystosowując ją do potrzeb kultu religijnego wnoszono tam różne przeróbki i zmiany.

O jej kształcie i pierwotnych rozmiarach można wnioskować na podstawie resztek domostw i urządzeń gospodarczych, które odkryto w pobliżu Groty. Od strony północnej w odległości kilku metrów od Groty znajduje się piwniczka, zwana popularnie ,Kuchnią Matki Boskiej“ między Grotą a "Kuchnią" jest połączenie. Powstało ono jednak dopiero w wiekach średnich.

Wspomniane pozostałości domostw, przypominające swym wyglądem mniej czy więcej pierwotny stan Groty Zwiastowania, rozrzucone są dość gęsto na terenie objętym poszukiwaniami.

Naturalne groty, w które teren skalisty jest bogaty, jak wskazują badania, starano się wykorzystać i dostosować do użytku 
codziennego. Niektóre $\mathrm{z}$ poszczególnych grot łączono za pomocą podziemnych chodników, jakby korytarzy, różnych co do długości nieraz po kilka metrów, ale o małym przekroju. Jeden np. z takich korytarzyków miał $52 \mathrm{~cm}$ szerokości i 74 głębokości. Groty o których mowa z zasady nie były miejscem stałego zamieszkania, nie stanowiły mieszkań, gdyż ślady na to nie wskazują. Wykorzystywano je raczej dla powiększenia obejścia domowego. Domy mieszkalne były ponad grotami na powierzchni.

Posuwając się po terenie poszukiwań natrafiono więc na następujące, bardziej charakterystyczne znaleziska. Od strony północnej nawy kościoła bizantyjskiego natrafiono na kamienną nieckę, będącą pozostałością dużej tłoczni do wina czy oliwy. Wyżłobieniem znajdującym się $w$ niecce wyciśnięty sok spływał do dużego naczynia. Obok miejsca, gdzie znajdowała się tłocznia była piwnica, gdzie na półkach przechowywano naczynia napełnione winem lub oliwą.

Tłocznia wraz ze szczątkami innych obiektów, jak kawałkiem schodów (dwa stopnie), prowadzących w głąb piwnicy, kilkoma spiżarniami, małymi grotami, stanowiły jeden duży kompleks jakiegoś obejścia domowego, gospodarczego, które mogło wystarczyć dla potrzeb jednej wielkiej rodziny.

Do tego kompleksu należy też wspomniana już „Kuchnia Matki Boskiej" dwie inne tłocznie, następnie cysterna, służąca do przechowywania wody na dłuższy okres czasu. Schodziło się do niej po stopniach.

W odległości kilkunastu metrów od opisanego zespołu znalezisk, posuwając się $w$ kierunku północno-zachodnim odkryto dwa obszerne pomieszczenia, po części wykute w skale, po części zaś uzupełnione przez dobudowane mury. Obydwa te pomieszczenia były połączone podziemnym korytarzem. Jedno z tych pomieszczeń stanowiło prawdopodobnie jakby warsztat, pewnego rodzaju pracownię, do której wchodziło się krótkim korytarzykiem. W narożniku tego pomieszczenia znajdował się mały piec średnicy $1,30 \mathrm{~m}$; przy ścianie zaś kamienna ławka. Pomieszczenie sąsiednie natomiast służyło, być może, jako pewnego rodzaju magazyn. Część tego pomieszczenia, tej komory, była wykorzystana prawdopodobnie jako stajnia. Wskazuje na to znaleziony tam żłóbek oraz w dwóch narożnikach uchwyty, służące do przywiązywania zwierząt.

Obydwa te pomieszczenia należały do całości obejścia domowego, ale też nie stanowiły mieszkań. Zabudowania mieszkalne jak i w poprzednim wypadku znajdowały się raczej ponad tymi dwoma obiektami, oczywiście, dawno już zniszczone.

Idąc znowu dalej, w odległości dalszych kilku metrów natrafiono na cztery stopnie, po których schodziło się do dużej groty $(9 \times 3 \mathrm{~m})$. Znaleziono $\mathrm{w}$ niej kilka urządzeń, stanowiących jakby 


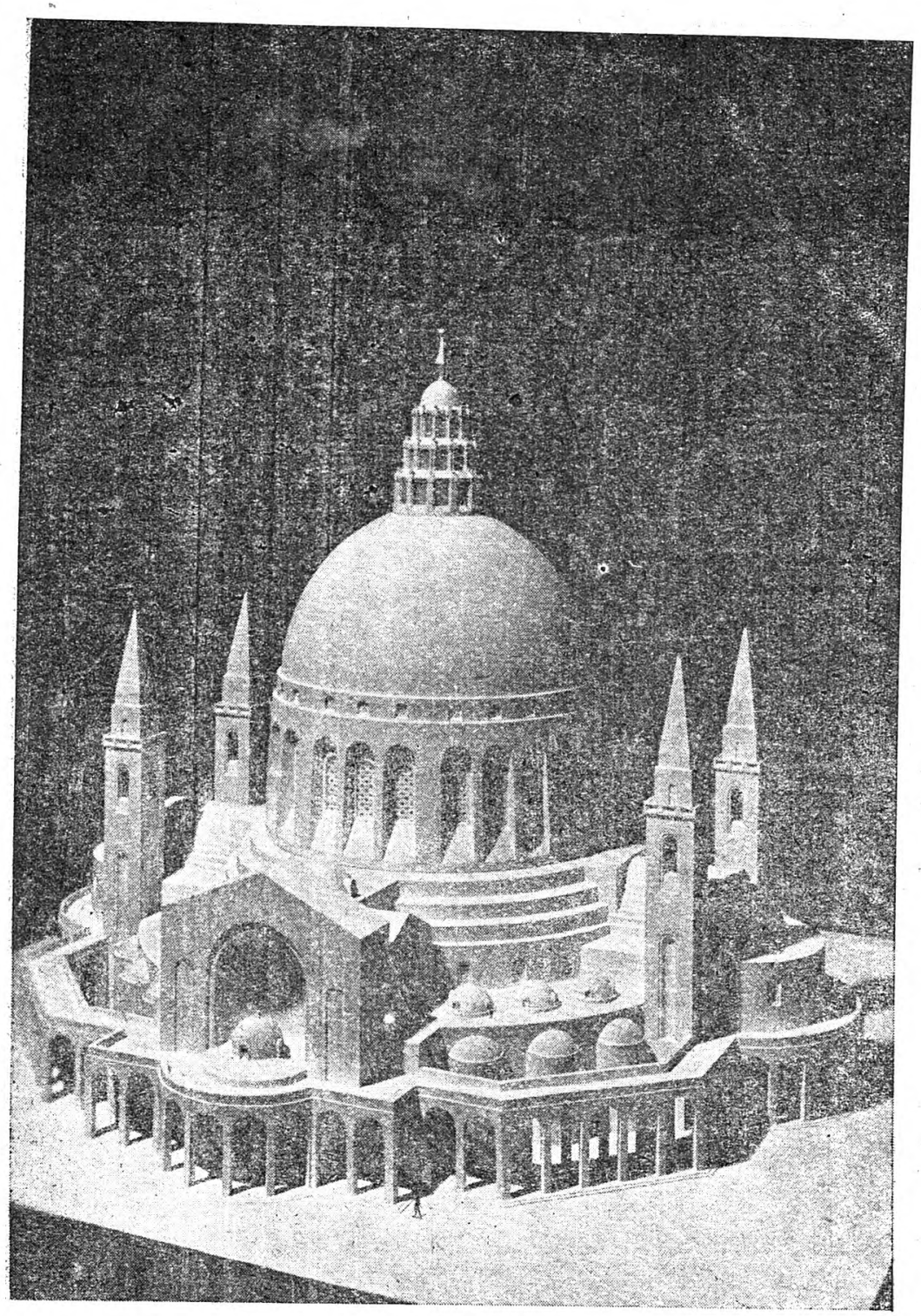

Projekt nowej Bazyliki w Nazaret 
spiżarnie. Znajdujące się z boku dwa otwory umożliwiały dopływ powietrza. Nic nie wskazuje, by i tutaj ktoś mieszkał.

Po stronie zachodniej małego kościoła bizantyjskiego znaleziska były nieliczne. Odkryto tam kilka spiżarń, dwie cysterny, kanał. podziemny długości kilku metrów, małą grotę oraz piec wapienny.

Wymienione obiekty wykopaliskowe wskazują, że cała ta przestrzeń była zamieszkana. Są liczne i różnorodne ślady ludzkiej gospodarki.

Charakterystyczne są też odnalezione w grotach, w zaściankach: skalnych resztki naczyń kuchennych, różnego rodzaju skorupy.

Do częściej spotykanych należą tu: kamienie do mielenia ziarna, następnie skorupy naczyń takich jak misy, czary itp. Spotyka się kawałki szkła z kielichów, waz, pucharów, oraz przedmioty ceramiczne jak lampki (kaganki), talerzyki itp. Ceramika jaką znaleziono najlepiej wskazuje, że osiedle to bez przerwy było zamieszkane.

$\mathrm{Z}$ epoki żelaza mamy tu pierwsze ślady zamieszkania (600 lat przed Chrystusem). Dość duża ilość naczyń, sprzętów, skorup glinianych odznacza się charakterystycznymi kształtami, cechami właściwymi dla tej epoki.

Znacznie mniej znalezisk pozostało $\mathrm{z}$ epoki hellenistycznej. Być może, że wtedy osiedle było bardzo małe. Częstsza jest już ceramika z czasów Herodów. Znaleziono między innymi bardzo charakterystyczne dla tej epoki resztki lampek, oraz ampułkę szklana. na olejki.

Spotyka się lampki o cechach właściwych dla epoki rzymskiej. Nie napotkano natomiast dotąd na ślady grobów z tej epoki. Najbliższy grób z czasów rzymskich znajduje się w odległości około. $60 \mathrm{~m}$ od Groty Zwiastowania.

Mylnie przypuszczano, że wnęki skalne powstałe przy wydobywaniu kamienia stanowiły groby. Badania wykazały, że przypuszczenie było fałszywe.

Dużo śladów w postaci pozostałości ceramiki mamy $z$ epoki bizantyjskiej. Sa to lampki, wszelkiego rodzaju naczynia, czary, misy, wielkie dzbany. Niemniej obfitują w ceramikę także wieki średnie.

Tak to skaliste wzgórze nazaretańskie przechowało w swym łonie dość dużo świadectw życia ludzkiego z epoki chrześcijańskiej i przedchrześcijańskiej.

$\mathrm{Na}$ podstawie tych znalezisk możemy jeszcze bardziej zbliżyć się do czasów, w których żyła święta Rodzina w Nazarecie, oraz. warunków i sposobów Jej bytowania.

Wloclawek Ks. KAZIMIERZ BARCKI 